\title{
Does Higher Education Curriculum Contribute to Prospective Teachers' Attitudes, Self-Efficacy and Motivation?
}

\author{
Morana Koludrović ${ }^{1, *} \&$ Ina Reić Ercegovac ${ }^{1}$ \\ ${ }^{1}$ Faculty of Humanities and Social Sciences Split, University of Split, 21000 Split, Put iza nove bolnice 10c, Croatia \\ *Correspondence: Faculty of Humanities and Social Sciences Split, University of Split, 21000 Split, Put iza nove \\ bolnice 10c, Croatia. E-mail: morana@ffst.hr
}

Received: January 16, 2017

Accepted: February 3, 2017 Online Published: February 17, 2017

doi:10.5430/wje.v7n1p93

URL: http://dx.doi.org/10.5430/wje.v7n1p93

\begin{abstract}
In Croatia, another comprehensive reform of the education system is being implemented. Although it proposes a number of reforms to the school system, we think that providing better training to future teachers during their studies would further contribute to the quality of education. The initial education of elementary and high school teachers is considerably different in terms of the number of courses where teaching competences are acquired, i.e. teaching courses, and the number of classes of these courses students take every week. Therefore, the initial hypothesis of the study was that students who take more teaching courses will prefer a democratic atmosphere, and will be more intrinsically motivated, more self-efficient and more satisfied with their course of study as compared to students who take fewer of these courses. A series of questionnaires was given to 383 students at teacher education institutions at the University of Split to examine their academic self-efficacy, motivation, satisfaction with the studies and to assess the quality of teaching atmosphere. The obtained results confirm the hypothesis that future teachers who take more teaching courses prefer a democratic atmosphere and are intrinsically more motivated. When explaining future teachers' attitudes towards a democratic teaching process, the predictive role of self-efficacy and satisfaction with the course of study was not determined.
\end{abstract}

Keywords: prospective teachers; self-efficacy; academic motivation; higher education curriculum

\section{Introduction}

Science, practice and everyday life continuously confirm the importance of the role of teachers in developing an individual at all levels of the educational process, i.e. from nursery school to higher education. The contemporary competence and co-constructivist approaches to education determine teachers' role by trying to define groups of competences that modern teachers should have. A modern teacher should be a leader with good organisational skills who is able to guide students. Teachers play an important role in encouraging students to develop a critical, active and creative attitude towards knowledge, in helping them to develop their emotional, social and problem-solving competences, in promoting lifelong learning, and in developing the potential for personal and social growth and well-being (Danielson, 2007; Common European Principles for Teacher Competences and Qualifications, 2005; Improving the Quality of Teacher Education, 2007; Levels of Autonomy and Responsibilities of Teachers in Europe, 2008). In order to help students develop all the aforementioned skills and competencies, prospective teachers should acquire them during their initial professional education. This, therefore, underlines the importance of establishing and redefining the quality of curriculum in educating prospective teachers. A modern teacher education curriculum should be based on the constructivist and competence approaches and lifelong learning that integrate theoretical teaching, research results, and practice. Thus, students would be trained in the course of their studies to become effective, competent, reflexive, and critical practitioners (Bhargava \& Pathy, 2011; Koludrovic, 2013; Domovic \& Vizek Vidovic, 2010). This view is further supported by the results of some studies showing that novice teachers who have been trained using traditional teaching methods have difficulties choosing appropriate teaching and learning strategies, assessing and evaluating students' knowledge, and seeking help when they need it. In addition, they do not have the necessary skills to adapt their own work to students' needs and interests (Bennett, 1993; Rijavec, Miljevic-Ridicki \& Vizek Vidovic, 2006). It has also been found that traditional approaches to teaching at teacher training colleges do not seem to change students' initial attitudes that they had before starting their studies. In 
addition, students consider knowledge thus gained irrelevant and useless, as they cannot implement the acquired theory into practice (Calderhead \& Robson, 1991; Joram \& Gabriel, 1998; Richardson, 1996). On the other hand, some research has shown that the use of problem- and project-based learning and reflexive and action-oriented approach in the initial education of prospective teachers contributes to more positive attitudes towards the teaching profession, enhances intrinsic motivation for learning and boosts academic performance (Martin, West, \& Bill, 2008; Koludrovic, 2013).

In Croatia, Initial Teacher Education is divided into two basic categories: primary school teachers and subject teachers. The former attend the five-year integrated Teacher Education course of study whose curriculum enables students to develop and acquire teaching competences during all five years. The latter are students with majors in both educational and non-educational fields who take teaching courses at the graduate level or after graduating as part of their retraining. There are two fundamental differences between these two groups: one is related to the aspects of motivation and the other to the curriculum and syllabus since they take different number of teaching courses and have different number of lessons. Teacher Education and Pedagogy students continuously attend pedagogical, psychological, and methodological courses during their course of study (Developmental Psychology, Educational Psychology, General Pedagogy, Didactics, School Pedagogy, Reform Pedagogy, Family Pedagogy, Psychology of Teaching, Partnership between Families and Schools, Special Pedagogy, Methodology of Curriculum Development, Media Pedagogy, Philosophy of Education, Sociology of Education with an average 4-5 ECTS per course). They are continuously exposed to the realities of teaching using field-based experiences to first get an insight into the teaching process in practice, and then teach classes under the supervision of a mentor. On the other hand, prospective subject teachers do not take teaching courses until the graduate level (such as Fundamentals of Pedagogy, Didactics, Sociology of Education, Educational Psychology and Methodology of subject(s) that they study. These courses usually have 5 ECTS each).

This research was triggered by significant differences in students' load and in the structure of the curricula between the two groups. We believe that students who continuously participate in field work and receive a constant teacher training will develop more positive attitudes towards the teaching profession and will develop a better understanding of the role of teachers in the teaching process. We think that in the course of their studies subject teachers do not develop sufficient competences they need to tackle the sensitive adolescent population they most commonly teach. A number of recent studies conducted in Croatia also show that pupils' self-esteem and self-efficacy, intrinsic motivation and academic achievement (Koludrovic \& Radnic, 2013; Koludrovic \& Reic Ercegovac, 2013; 2014) significantly decrease with the transition from class to subject teaching/learning. In addition to the adolescents' developmental characteristics, this can be attributed to the lower level of competence of subject teachers. The results of some studies show that primary school teachers experience less stress in their teaching profession, and that, in comparison to subject teachers, they assess themselves as being more satisfied with their job (Koludrovic, Jukic, \& Reic Ercegovac, 2009). This can be attributed to their greater competence to deal with problems that arise during the teaching process which they have been systematically acquiring during their initial teacher education.

\subsection{Academic Motivation and Self-efficacy of Prospective Teachers}

For the purpose of this paper, academic motivation is defined in the context of Self-Determination Theory (Ryan \& Deci, 2000). The continuum of self-determination ranges from amotivation, as complete disengagement and lack of interest in performing some tasks in which the behaviour is the least regulated, to the intrinsic motivation that is generated by internal interests and goals of the individual, which he identifies as being personally relevant (Vansteenkiste, Lens, \& Deci, 2006; Gagne \& Deci, 2005). According to the self-determination theory, intrinsically motivated behaviour is fully autonomous, while extrinsic motivation can vary in terms of the degree of autonomy versus control (Gagne \& Deci, 2005; Vansteenkiste et al., 2006). In the academic context, intrinsically motivated individuals use deep-processing strategies, perform better academically, but also perceive themselves as having greater competence, are more self-efficient and autonomous, and feel more satisfied with their performance at various activities (Ryan \& Deci, 2000; Eccles \& Wigfield, 2002; Schunk, 1991; Isiksal, 2010; Gagne \& Deci, 2005). Learning about the kinds and types of motivation and particularly about the ways to motivate individuals in the academic context, seems extremely important when developing the curriculum and selecting activities and tasks which in the academic context need to be more interesting and challenging so that individuals are intrinsically and autonomously motivated. Motivationally optimal learning environment is the one in which the curriculum is designed to enable individuals to acquire knowledge, skills and abilities that are relevant to them and applicable to their lives outside of school in real-life situations. There should always be a balance between the breadth and depth of educational content so that students can learn the content with understanding (Brophy, 1999). When developing a curriculum that is based on self-regulated learning and that fosters autonomous motivation, all objectives, activities 
and tasks must be directed to the development of critical thinking and creativity by using problem-solving strategies and active learning (Brophy, 1999; Nilsen, 2009).

In the education of prospective teachers, developing students' self-efficacy has a dual role as teacher's self-efficacy contributes to the quality of the educational process, but also affects students' achievements, motivation and their trust in their own self-efficacy (Tschannen-Moran \& Woolfolk Hoy, 2001; Woolfolk Hoy, 2000). Woolfolk Hoy (2000) points out that the most significant impact on the development of prospective teachers' self-efficacy is the experience acquired during their initial teacher education. This is confirmed by the results of a research that has shown that students with low self-efficacy are more directed towards control and strict class rules, develop pessimistic attitudes towards pupils and their learning, and believe that punishment and extrinsic rewards encourage pupils to learn. Given the fact that these teachers' characteristics of low self-efficacy are in contradiction with the contemporary competence approach to education in schools, it is extremely important to develop prospective teachers' self-efficacy in the course of their studies.

From all the above stated, it is clear that prospective teachers should have a broad knowledge of motivation, self-regulated learning, and modern teaching and learning strategies. They should also encourage individuals to actively and meaningfully understand the content, allow them to feel a sense of success and confidence in their work and ensure a social environment that favours a pleasant atmosphere of cooperation and communication (Brophy, 1999; Nilsen, 2009). In order to achieve these objectives, initial teacher education needs to be restructured in a way that more emphasis is placed on the areas related to motivational and social aspects of teaching.

\subsection{Research Aims and Problems}

The aim of this study was to investigate prospective teachers' academic motivation, self-efficacy and attitudes towards the teaching profession given the differences in the level (undergraduate and graduate studies) and type of education (pedagogical, psychological and didactic courses during the entire course of study or only at the graduate level). The main hypothesis of the study was that Teacher Education and Pedagogy students, because of the structure of their curricula, would be more intrinsically motivated, self-efficient and satisfied with their studies and would tend to conduct their classes more democratically as compared to other survey participants. Given the level of studies, it was also expected that graduate students would, as compared to undergraduate students, be more intrinsically motivated, self-efficient and satisfied with their studies and would tend to democratically conduct classes. Last research problem was to determine the predictive value of the courses and levels of study, all aspects of motivation, self-efficacy and satisfaction with the studies that could be used to explain the differences in teacher's attitudes. It was expected that the most important predictors would be the course of studies and students' intrinsic motivation, i.e. that Teacher Education or Pedagogy graduate students, as well as those with a higher degree of intrinsic motivation would express more positive attitudes towards creating a democratic atmosphere in the classroom.

\section{Methods}

\subsection{Participants}

The research included convenience sample of 383 undergraduate and graduate students at the Faculty of Philosophy and the Faculty of Kinesiology, University of Split. As presented in Table 1, the participants were divided into four groups based on two main independent variables: level of study (undergraduate and graduate studies) and course of study. One group consisted of prospective primary school teachers and educationists, and the other of teachers of languages and literature, history, history of art, philosophy, and physical education. The participants were divided with regard to the number of teaching courses in the curriculum. At the Integrated Teacher Education and undergraduate and graduate Pedagogy courses of study, a range of courses aimed at developing prospective teachers' teaching competences are taught during their courses of study. On the other hand, other students (i.e. language and literature, history, history of art, philosophy, and physical education ones) take teaching courses only at the graduate level. Finally, although all the participants involved in the study at the end of their formal education obtain a degree that allows them to teach (in Croatian educational system), it is very likely that the level of their competences and their attitudes towards the teaching profession will differ because they did not take the same number of teacher training courses nor for the same period of time. Because of the aforementioned, it seemed useful to investigate the differences between those students in the variables relevant to teaching. 
Table 1. Sample Structure with Regard to the Level and Course of Study

\begin{tabular}{lccc}
\hline & Bachelor & Master & Total \\
\hline Primary Teacher and Pedagogy & 145 & 63 & 208 \\
Subject Teacher & 110 & 65 & 180 \\
Total & 255 & 128 & 383 \\
\hline
\end{tabular}

\subsection{Research Instruments}

Academic Motivation Scale (AMS-C28 CEGEP version, Vallerand et al., 1992) is based on the theory of self-determination and is composed of 28 items. The participants' task was to assess the level of agreement with each statement on a 1 to 7 Likert scale (1 - strongly disagree; 7 -strongly agree). The original seven-factor scale consists of the following factors: amotivation, three types of extrinsic motivation (external, introjected and identified regulation), and three types of intrinsic motivation (knowledge, achievement and experience). Although some studies have confirmed such a structure (Isiksal, 2010), some Croatian research has indicated that the subscales of intrinsic motivation are mainly grouped into one (Muller \& Palekcic, 2005) or two factors (Koludrovic, 2013; Koludrovic \& Reic Ercegovac, 2015).

Table 2 shows the factor structure which was obtained using an exploratory factor analysis using principal components with varimax normalized rotation. It is evident that the items were not distributed by factors according to the proposed original structure, but all items related to intrinsic motivation (knowledge, achievement and experience) were assigned to one factor in addition to an item from the factors that were in the original attributed to the identified regulation (Table 2). In terms of context, it is justified to attribute the item, which in the original belonged to the identified regulation, to intrinsic motivation because identified regulation is partly autonomous motivation and since it determines the activities which, although originally imposed on an individual, he accepts as being personally important. The remaining three items of identified motivation and items belonging to the subscales of external regulation and introjected regulation make the second factor which refers to extrinsic motivation. The items on the amotivation subscale were all classified as in the original. The psychometric characteristics of the developed subscales are shown in Table 2.

Table 2. The Psychometric Properties of the Academic Motivation Scale

\begin{tabular}{lccc}
\hline & Intrinsic motivation & Extrinsic motivation & Amotivation \\
\hline percentage of explained variance & $24 \%$ & $19 \%$ & $13 \%$ \\
Cronbach alpha & .92 & .88 & .82 \\
M (SD) & $61.29(14.22)$ & $51.14(12.82)$ & $5.74(3.31)$ \\
Range & $16-91$ & $19-77$ & $4-28$ \\
Average inter-item correlation & .47 & .41 & .59 \\
\hline
\end{tabular}

College Academic Self - Efficacy Scale (Owen \& Froman, 1988) measures self-efficacy at the university level and, as opposed to other scales that measure academic self-efficacy in specific subject areas, it is used to examine general academic self-efficacy, regardless of the individual subjects. The scale contains 33 items, and the participants' task was to evaluate the degree of agreement for each statement on a 1 to 5 Likert scale with 1 being 'strongly disagree' and 5 'strongly agree'. The original scale had a three-factor structure in which the factors represented social situation, cognitive operations and techniques and technology skills, and the confidence interval of subscales ranged from Cronbach's alpha between .85 and .90 (Owen \& Froman, 1988). It should be noted that the authors recommended the use of one-factor structure that had also been used in some previous studies (Choi, 2005; Lampert, 2007).

Exploratory factor analysis in this study revealed a three-factor structure (Table 3), but the resulting structure is different from the original one. To some extent, the first and the second factor match the original structure. The first factor isolated items related to the cognitive aspect, while the second factor isolated items related to the social aspect of self-efficacy. The third factor, unlike the original, isolated the items related to regular class attendance. Given the content and the logical structure of the factors and satisfactory reliability coefficients of the three subscales, the 
results were grouped into linear combinations of evaluation of items that make up each subscale. Psychometric properties of the subscales are given in Table 3 .

Table 3. Psychometric Properties of the Academic Self-efficacy Scale

\begin{tabular}{lccc}
\hline & $\begin{array}{c}\text { Cognitive } \\
\text { self-efficacy }\end{array}$ & $\begin{array}{c}\text { Social } \\
\text { self-efficacy }\end{array}$ & $\begin{array}{c}\text { Regular class } \\
\text { attendance }\end{array}$ \\
\hline percentage of explained variance & $17 \%$ & $12 \%$ & $8 \%$ \\
Cronbach's alpha & .86 & .75 & .71 \\
M (SD) & $69.74(9.39)$ & $33.64(7.38)$ & $12.00(2.25)$ \\
Range & $40-94$ & $16-81$ & $3-15$ \\
Average inter-item correlation & .28 & .26 & .49 \\
\hline
\end{tabular}

Minnesota Teacher Attitude Inventory (MTAI, Cook, Leeds, \& Callis, 1951) in the original consists of 150 items, and successful teaching is measured by the social and emotional atmosphere (Callis \& Ferguson, 1953, Cook et al., 1951). Attitudes measured by this instrument are key to forecasting the type of social atmosphere that a teacher will create in his classroom (Cook et al., 1951), and can range from a very authoritarian atmosphere that is characterized by rigid rules and regulations and where students are extrinsically motivated, to a democratic atmosphere that is characterized by flexibility in work and behaviour and which highlights the importance of student participation and high level of students' intrinsic motivation (Callis \& Ferguson, 1953). The inventory can be used to research prospective teacher's attitudes towards students and the teaching profession (Cook et al., 1951; Bell, 1976).

In this study, the customized version of the inventory of 28 items was used as it had already proven its satisfactory psychometric properties (Koludrovic, 2013). Participants' task was to rate the given items on a 5-point Likert scale ( 1 - 'strongly disagree', 5 - 'strongly agree'). Since several items did not meet the criteria for saturation on one factor, they were not included in the analysis. After reverse scoring was applied on the negative items, the total result was formed as a linear combination of the rating of the remaining 23 items, where a higher score indicated a tendency to creating a more authoritative classroom atmosphere. The average score on the scale was $\mathrm{M}=60.58$ (SD $=14.31$ ). The reliability of the scale was satisfactory (Cronbach's alpha was .87). The results ranged from 26 to 105 , and the average correlation between the items was $r=.24$.

The satisfaction questionnaire developed for this study consisted of five items, which measured the overall satisfaction with the studies. Participants' task was to indicate their agreement with each of the items on a 5-point Likert scale ( 1 - 'strongly disagree', 5 - 'strongly agree'). One extracted factor accounted for $55 \%$ of the total variance with a satisfactory reliability of $\alpha=.77$. The average score on the scale was $\mathrm{M}=21.23(\mathrm{SD}=2.85)$ and the results ranged from 9 to 25 .

\section{Results and Discussion}

The aim of this study was to investigate the differences in academic motivation, self-efficacy and attitudes of prospective teachers towards the teaching profession considering the differences in the level (undergraduate and graduate studies) and the type of education (pedagogical, psychological and didactic courses during the entire course of study or only at the graduate level).

The first research problem addressed in this study was to examine whether the differences in prospective teachers' in motivation were related to the level and course of study. The initial hypothesis was that Teacher Education and Pedagogy students, in comparison with the other group of participants, would be more intrinsically motivated, while significant differences in the level of amotivation were not expected. Furthermore, it was expected that graduate students would be more intrinsically motivated, less extrinsically motivated and less amotivated than undergraduate students. In order to investigate the above, a series of two-way analysis of variance with the level and course of study as independent variables was performed. Table 4 shows the results of these analyses for the variables of motivation. 
Table 4. Results of Two-Way Analysis of Variance to Test the Differences in Motivation with Regard to the Course and Level of Study

\begin{tabular}{|c|c|c|c|c|c|c|}
\hline \multicolumn{3}{|r|}{ independent variables } & \multirow{3}{*}{$\begin{array}{c}\mathrm{N} \\
255\end{array}$} & \multirow{2}{*}{$\begin{array}{c}\mathrm{M} \\
4.72\end{array}$} & \multirow{2}{*}{$\begin{array}{l}\text { SD } \\
.06\end{array}$} & \multirow{2}{*}{$\begin{array}{l}\mathrm{F}(\mathrm{df}= \\
1,379) \\
9.92 * *\end{array}$} \\
\hline \multirow{9}{*}{ 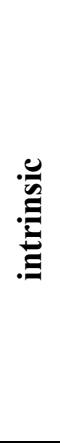 } & Level & Bacholor & & & & \\
\hline & & & & & & \\
\hline & & Master & 128 & 5.08 & .09 & \\
\hline & Course & Primary Teacher and Pedagogy & 208 & 4.83 & .08 & \\
\hline & of study & Subject Teacher & 175 & 4.98 & .08 & 1.90 \\
\hline & Level x & Bachelor, Primary Teacher and Pedagogy & 145 & 4.63 & .09 & \\
\hline & Course & Bachelor, Subject Teacher & 110 & 4.82 & .10 & \\
\hline & of study & Master, Primary Teacher and Pedagogy & 63 & 5.02 & .13 & .064 \\
\hline & & Master, Subject Teacher & 65 & 5.15 & .13 & \\
\hline \multirow{8}{*}{ 总 } & Level & Bachelor & 255 & 4.87 & .07 & $13.49 * *$ \\
\hline & & Master & 128 & 4.42 & .10 & \\
\hline & Course & Primary Teacher and Pedagogy & 208 & 4.67 & .09 & \\
\hline & of study & Subject Teacher & 175 & 4.63 & .09 & .11 \\
\hline & Level x & Bachelor, Primary Teacher and Pedagogy & 145 & 4.83 & .09 & \\
\hline & Course & Bachelor, Subject Teacher & 110 & 4.91 & .11 & .83 \\
\hline & of study & Master, Primary Teacher and Pedagogy & 63 & 4.50 & .14 & \\
\hline & & Master, Subject Teacher & 65 & 4.34 & .14 & \\
\hline \multirow{8}{*}{ 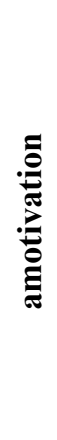 } & Level & Bachelor & 255 & 1.52 & .05 & 3.06 \\
\hline & & Master & 128 & 1.36 & .07 & \\
\hline & Course & Primary Teacher and Pedagogy & 208 & 1.37 & .06 & \\
\hline & of study & Subject Teacher & 175 & 1.50 & .07 & 2.02 \\
\hline & Level x & Bachelor, Primary Teacher and Pedagogy & 145 & 1.40 & .07 & \\
\hline & Course & Bachelor, Subject Teacher & 110 & 1.63 & .08 & \\
\hline & of study & Master, Primary Teacher and Pedagogy & 63 & 1.34 & .11 & 1.13 \\
\hline & & Master, Subject Teacher & 65 & 1.37 & .10 & \\
\hline
\end{tabular}

$*_{p}<.05 ; * * p<.01$

Contrary to the expectations, the obtained results show that there are no significant differences either in the intrinsic or extrinsic motivation between Teacher Education and Pedagogy students and other research participants. Given the fact that the interest in all these studies is extremely strong and that high school students who enrol into these studies are those with high academic achievement, it is very likely that they choose exactly what they want to study and that they are intrinsically motivated for their specific course of study as evidenced by relatively high arithmetic means for both courses of study (Table 4).

Furthermore, Table 4 shows that the level of study has a significant effect on intrinsic and extrinsic motivation, i.e. graduate students are significantly more intrinsically motivated as compared to the undergraduate students who are more extrinsically motivated as compared to graduate students. This result is in line with our expectations and it may be claimed that, in addition to older students being more committed to the course study they have enrolled, they, as compared to younger students, have clearer expectations of the profession they have chosen and are more intrinsically motivated to acquire competences necessary to perform well in their future careers. Finally, due to a certain dropout rate at the graduate level those students who decide to pursue their studies at the graduate level are more highly motivated to complete their studies. The results have partially confirmed the initial hypothesis that graduate students are more intrinsically motivated than their younger colleagues. The hypothesis that Teacher 
Education and Pedagogy students in relation to the other participants are more intrinsically motivated has not been confirmed.

The second research problem investigated the difference in prospective teachers' self-efficacy with regard to the level and course of study. It was assumed that Teacher Education and Pedagogy students, as compared to the other group of participants, and graduate students as compared to undergraduate ones, would be more self-efficient.

Table 5. Results of Two-Way Analysis of Variance to Test the Difference in Self-Efficacy with Regard to the Course and Level of Study

\begin{tabular}{|c|c|c|c|c|c|c|}
\hline & & independent variables & $\mathrm{N}$ & M & $\mathrm{sd}$ & $\mathrm{F}(\mathrm{df}=$ \\
\hline & Level & Bachelor & 255 & 361 & 03 & $2107 * *$ \\
\hline & & Master & 128 & 3.84 & .04 & \\
\hline & Course & Primary Teacher and Pedagogy & 208 & 3.83 & .04 & \\
\hline$:$ & of study & Subject Teacher & 175 & 3.62 & .04 & $16.96^{* *}$ \\
\hline 50 & Level $\mathrm{x}$ & Bachelor, Primary Teacher and Pedagogy & 145 & 3.75 & .04 & \\
\hline & Course & Bachelor, Subject Teacher & 110 & 3.47 & .04 & \\
\hline & of study & Master, Primary Teacher and Pedagogy & 63 & 3.91 & .06 & 1.69 \\
\hline & & Master, Subject Teacher & 65 & 3.77 & .06 & \\
\hline & Level & Bachelor & 255 & 3.05 & .04 & $5.69 *$ \\
\hline & & Master & 128 & 3.22 & .06 & \\
\hline & Course & Primary Teacher and Pedagogy & 208 & 3.21 & .05 & \\
\hline בg & of study & Subject Teacher & 175 & 3.06 & .05 & $4.28 *$ \\
\hline $\mathscr{n}$ & Level $\mathrm{x}$ & Bachelor, Primary Teacher and Pedagogy & 145 & 3.07 & .06 & \\
\hline & Course & Bachelor, Subject Teacher & 110 & 3.03 & .06 & \\
\hline & of study & Master, Primary Teacher and Pedagogy & 63 & 3.36 & .08 & 2.41 \\
\hline & & Master, Subject Teacher & 65 & 3.09 & .08 & \\
\hline & Level & Bachelor & 255 & 4.07 & .04 & $6.51^{*}$ \\
\hline 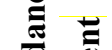 & & Master & 128 & 3.86 & .07 & \\
\hline$\Xi$ & Course & Primary Teacher and Pedagogy & 208 & 3.99 & .06 & \\
\hline$\underset{\Xi}{E}$ & of study & Subject Teacher & 175 & 3.94 & .06 & .46 \\
\hline$\frac{\pi}{0} \frac{y}{\pi}$ & Level $\mathrm{x}$ & Bachelor, Primary Teacher and Pedagogy & 145 & 4.09 & .06 & \\
\hline & Course & Bachelor, Subject Teacher & 110 & 4.05 & .07 & \\
\hline 5 & of study & Master, Primary Teacher and Pedagogy & 63 & 3.90 & .09 & .05 \\
\hline & & Master, Subject Teacher & 65 & 3.83 & .09 & \\
\hline
\end{tabular}

${ }^{*} p<.05 ; * * p<.01$

The results presented in Table 5 show that the level and course of study have a significant effect on cognitive and social aspects of self-efficacy, while only the level of study has an effect on how regularly the students fulfil their academic tasks, whereby bachelor students are more regular as compared to master students. On the other hand, graduate students are more cognitively and socially self-efficient as compared to undergraduates. In terms of the course of study, better results in both aspects of self-efficacy were achieved by Teacher Education and Pedagogy students, i.e. students who from the first year of study focus on pedagogical, psychological and didactic areas. In pre-service teacher training, developing self-efficacy is an extremely important issue because previous studies have shown that prospective teachers often feel incapable and inefficient to perform as teachers (Joram \& Gabriel, 1998; Richardson, 1996). If students during their studies see themselves as being self-efficient and therefore competent to 
teach in the future, it can be assumed that they will have a much greater chance of being successful teachers.

The third research problem examined the possible differences in attitudes towards the teaching profession among prospective teachers with regard to the level and course of studies. It was assumed that Teacher Education and Pedagogy students, as compared to the other group of participants, would express more positive attitudes towards the democratic teaching atmosphere because all the courses related to the acquisition of teaching competences on these two courses of study are based on the same paradigm that promotes co-constructivist approach to learning and teaching, prepares students for the role of teachers as critical and reflective practitioners, and emphasizes the importance of a democratic educational environment in the future teaching practice. The analysis of learning outcomes of the aforementioned courses of study shows that a significant emphasis is put on analysis, discussion, evaluation of the studied material and the promotion of student-oriented teaching and not on teacher-oriented teaching where teachers is seen the only authority whose task is to transmit the teaching content.

It was also assumed that graduate students, as compared to undergraduate ones, would express more positive attitudes towards democratic teaching atmosphere because at graduate level all of the participants take courses where teachers' competences are taught, where the role of teachers as creative, reflexive and critical practitioners is emphasized, and where they are systematically encouraged to think about ways of achieving a democratic teaching atmosphere and structuring classes that are primarily aimed at students and that do not only concentrate on the course content.

Table 6 shows that Teacher Education and Pedagogy students on the one hand and master level students compared to bachelor students on the other, expressed a more positive attitude towards the democratic style of leadership and class management that implicitly points to a better recognition of contemporary trends in teaching.

Table 6. Results of a Two-Way Analysis of Variance to Test the Differences in Teacher's Attitudes with Regard to the Course and Level of Study

\begin{tabular}{lrrrrr}
\hline & \multicolumn{1}{l}{ independent variables } & $\mathrm{N}$ & $\mathrm{M}$ & $\mathrm{sd}$ & $\mathrm{F}(\mathrm{df}=$ \\
& & & & $1,379)$ \\
\hline Level & Bachelor & 255 & 2.74 & .04 & $29.51^{* *}$ \\
& Master & 128 & 2.39 & .05 & \\
Course of & Primary Teacher and Pedagogy & 208 & 2.40 & .04 & $24.51^{* *}$ \\
study & Subject Teacher & 175 & 2.73 & .05 & \\
Level x & Bachelor, Primary Teacher and Pedagogy & 145 & 2.57 & .05 & \\
Course of & Bachelor, Subject Teacher & 110 & 2.91 & .06 & \\
study & Master, Primary Teacher and Pedagogy & 63 & 2.24 & .07 & .14 \\
& Master, Subject Teacher & 65 & 2.54 & .07 & \\
\hline
\end{tabular}

${ }^{*} p<.05 ; * * p<.01$

Teacher Education and Pedagogy students, unlike other research participants, take courses that are based on (co)constructivist paradigm. These students from the beginning of their studies take many courses aimed at the acquisition of pedagogical, psychological and methodological competences that probably contribute to a better understanding of teaching and learning issues and that in a more complete way prepare them to meet the challenges of classroom dynamics. This is supported by several previous studies that have shown that when higher education teachers promote democratic atmosphere in their own classes, they instil such attitudes among students who are then more likely to display such behaviour in their future teaching (Gourneau 2005; Pollard, Collins, Anderson et al., 2006; Koludrovic, 2013). Finally, in the course of their studies, Teacher Education and Pedagogy students get field-based experience and teach classes, and therefore, have the opportunity to empirically identify the characteristics of a quality teaching process and the benefits of democratically conducted classes.

The fourth research problem examined differences in satisfaction with the studies with regard to the level and course of studies. The hypothesis was that graduate students would be more satisfied with their studies as compared to undergraduate students and that Pedagogy and Teacher Education students would be more satisfied with their courses of study given that they are strongly student-oriented rather than teacher-oriented teaching given their strong orientation towards co-constructivist approach to learning. The obtained results confirm the initial hypothesis and 
prove that graduate students are more satisfied than undergraduate ones and that Teacher Education and Pedagogy students are more satisfied with their courses of studies than students of other study groups who are being educated for the teaching profession at the graduate level (Table 7).

Table 7. Results of Two-Way Analysis of Variance to Test the Difference in Satisfaction with the Studies With Regard to the Course and Level of Study

\begin{tabular}{lrrrrc}
\hline & \multicolumn{1}{l}{$\begin{array}{l}\text { independent variables } \\
\text { Level }\end{array}$} & $\mathrm{N}$ & $\mathrm{M}$ & $\mathrm{sd}$ & $\begin{array}{c}\mathrm{F}(\mathrm{df}= \\
1,379)\end{array}$ \\
& Bachelor & 255 & 4.15 & .04 & $15.82^{* *}$ \\
Course of & Master & 128 & 4.40 & .05 & \\
study & Primary Teacher and Pedagogy & 208 & 4.41 & .04 & $16.87^{* *}$ \\
Level x & Subject Teacher & 175 & 4.14 & .05 & \\
Course of & Bachelor, Primary Teacher and Pedagogy & 145 & 4.25 & .05 & \\
study & Bachelor, Subject Teacher & 110 & 4.05 & .06 & \\
& Master, Primary Teacher and Pedagogy & 63 & 4.57 & .07 & 1.12 \\
\hline & Master, Subject Teacher & 65 & 4.24 & .07 & \\
\hline
\end{tabular}

${ }^{*} p<.05 ; * * p<.01$

The last research problem was to determine the predictive value of the course and level of study, all aspects of motivation, self-efficacy and satisfaction with the studies to explain individual differences in teachers' attitudes. It was expected that the most important predictors would be the course of study and students' intrinsic motivation, i.e. that graduate Teacher Education and Pedagogy students, as well as those with greater intrinsic motivation would show more positive attitudes towards the creation of a democratic atmosphere in the classroom.

Table 8. Results of the HRA with Teacher Attitudes as a Criterion

\begin{tabular}{|c|c|c|c|c|c|c|}
\hline \multirow{3}{*}{$1^{\mathrm{st}}$ step } & $\mathbf{R}$ & $\mathbf{R}^{2}$ & $\mathbf{R}$ & $F(d f)$ & $\beta$ & $(\beta)$ \\
\hline & .35 & .13 & & $27.17 * *$ & & \\
\hline & & & & $(2,380)$ & & \\
\hline level of study & & & & & $-.26 * *$ & $\left(-.16^{* *}\right)$ \\
\hline course of study & & & & & $.26 * *$ & $\left(.26^{* *}\right)$ \\
\hline $2^{\text {nd }}$ step & .45 & .21 & $.08^{*}$ & $19.64 * *$ & & \\
\hline motivation & & & & $(5,377)$ & & \\
\hline intrinsic & & & & & $-.18 * *$ & $\left(-.16^{*}\right)$ \\
\hline extrinsic & & & & & $.32 * *$ & $(.30 * *)$ \\
\hline amotivation & & & & & .01 & \\
\hline $3^{\text {rd }}$ step & .47 & .22 & .01 & $12.90 * *$ & & \\
\hline self-efficacy & & & & $(8,374)$ & & \\
\hline cognitive & & & & & -.08 & \\
\hline social & & & & & -.02 & \\
\hline regular class attendance & & & & & .08 & \\
\hline $4^{\text {th }}$ step & .47 & .22 & .00 & $11.61 * *$ & .06 & \\
\hline $\begin{array}{l}\text { satisfaction with the course of } \\
\text { study }\end{array}$ & & & & $(9,373)$ & & \\
\hline
\end{tabular}

${ }^{*} p<.05 ; * * p<.01$ 
The results of the conducted HRA with teacher attitudes as a criterion show that greater intrinsic motivation and lower extrinsic motivation (Table 8) are significant predictors of positive attitudes towards the democratic teaching process in addition to the aforementioned courses of studies (Teacher Education and Pedagogy) and levels of study (graduate). It can be concluded that the democratic teaching process is preferred by students who take more pedagogical, psychological and methodological courses, as well as by those who are more intrinsically motivated by their studies and chosen profession. This confirms the initial hypothesis on the predictive value of the course and level of study and students' intrinsic motivation in explaining prospective teachers' attitudes towards democratic teaching atmosphere. When prospective teachers' attitudes and preferences towards democratic teaching were being researched, the predictive role of self-efficacy or satisfaction with the studies was not established.

\section{Conclusion}

This study has some limitations that need to be addressed. First of all, sample included students from only one university and only in the area of social sciences and humanities. Secondly, research design was correlational, hence the possibility of drawing strict conclusions is limited. Future research should include more heterogeneous sample and longitudinal design which would enable monitoring key variables in time. Nevertheless, the obtained results speak in favour of the fact that intrinsically motivated students, who during their studies have several courses aimed at the acquisition of teaching competences, prefer to encourage democratic teaching, i.e. understand the organisation of modern student-oriented teaching which is based on the constructivist and competence approach to education. This confirms the initial aim of this paper, i.e. that future teachers (of language and literature, history, philosophy, physical education and history of art) should have more courses in which they would develop teaching competences and in which theory and practice would be linked.

As already stated, the impetus for this study was a discrepancy between teachers' competences acquired by teachers and educationist as compared to students of other majors who take teaching courses only at the graduate level. It seems that introducing additional courses from the field of teacher competences would contribute to a better understanding of contemporary educational theory and practice of all prospective teachers, and then indirectly it would in the long run lead to a higher quality of the education system as a whole.

Therefore, it seems more appropriate that instead of continuously implementing reforms 'from above', real reforms in Croatia should begin during studies especially at those faculties at universities in Croatia whose graduates will also become teachers, i.e. language and literature, history, philosophy, physical education, history of art and maybe even natural sciences majors.

\section{References}

Bell, J. A. (1976). An Investigation of a Short Form of the Minnesota Teacher Attitude Inventory. Paper presented at the Annual Meeting of the American Educational Research Association, San Francisco, April 19-23. Retrieved from http://files.eric.ed.gov/fulltext/ED126130.pdf

Bennett, N. (1993). Knowledge basis for learning to teach. In N. Bennett \& C. Carre (Eds.), Learning to Teach (pp.1-17). London: Routledge.

Bhargava, A., \& Pathy, M. (2011). Perception of Student Teachers about Teaching Competencies. American International Journal of Contemporary Research, 1(1), 77-81.

Brophy, J. (1999). Toward a Model of the Value Aspects of Motivation in Education: Developing Appreciation for Particular Learning Domains and Activities. Educational Psychologist, 34(2), 75-85. https://doi.org/10.1207/s15326985ep3402_1

Calderhead, J., \& Robson, M. (1991). Images of Teaching: Student Teachers' Early Conceptions of Classroom Practice. Teaching and Teacher Education, 7(1), 1-8. https://doi.org/10.1016/0742-051X(91)90053-R

Callis, R., \& Ferguson, J. L. (1953). Cluster Analysis of the Minnesota Teacher Attitude Inventory. University of Missouri: Department of Psychology. - Technical Report No. 2. Retrieved from http://www.dtic.mil/dtic/tr/fulltext/u2/012404.pdf

Choi, N. (2005). Self-efficacy and Self-concept as Predictors of College Students' Academic Performance. Psychology in the Schools, 42(2), 197-205.

Common European Principles for Teacher Competences and Qualifications. (2005). Retrieved September 8, 2015 from http://www.atee1.org/uploads/EUpolicies/common_eur_principles_en.pdf 
Cook, W. W., Leeds, C. H., \& Callis, R. (1951). Minnesota Teacher Attitude Inventory Manual. New York: The Psychological Corporation.

Danielson, C. (2007). Enhancing Professional Practice: A Framework for Teaching. Virginia: Association for Supervision and Curriculum Development.

Domovic, V., \& Vizek Vidovic, V. (2010). Development of quality culture in initial teacher education in Croatia. In B. Hudson, P. Zgaga, \& B. Astrand (Eds.), Advancing Quality Cultures for Teacher Education in Europe: Tensions and Opportunities (pp. 105-120). Umea: Umea School of Education.

Eccles, J. S., \& Wigfield, A. (2002). Motivational beliefs, values and goals. Annual Review of Psychology, 53, 109-132. https://doi.org/0.1146/annurev.psych.53.100901.135153

Fairchild, A. J., Horst, S. J., Finney, S. J., \& Barron, K. E. (2005). Evaluating New and Existing Validity Evidence for the Academic Motivation Scale. Contemporary Educational Psychology, 30(3), 331-358. https://doi.org/10.1016/j.cedpsych.2004.11.001

Ferla, J., Valcke, M., \& Cai, Y. (2009). Academic Self-Efficacy and Academic Self-Concept: Reconsidering Structural Relationships. Learning and Individual Differences, 19(4), 499-505. https://doi.org/10.1016/j.lindif.2009.05.004

Gagne, M., \& Deci, E. L. (2005). Self-Determination Theory and Work Motivation. Journal of Organizational Behavior, 26(4), 331-362. https://doi.org/10.1002/job.322

Improving the Quality of Teacher Education. Communication from the Commission to the Council and the European Parliament. (2007). Retrieved August $10, \quad 2015$ from http://eur-lex.europa.eu/legal-content/EN/TXT/PDF/?uri=CELEX:52007DC0392\&from=EN

Isiksal, M. (2010). A Comparative Study on Undergraduate Students' Academic Motivation and Academic Self-Concept. The Spanish Journal of Psychology, 13(2), 572-585. https://doi.org/10.1017/S1138741600002250

Joram, E., \& Gabriele, A. (1998). Preservice Teacher's Prior Beliefs: Transforming Obstacles into Opportunities. Teaching and Teacher Education, 14(2), 175-191. https://doi.org/10.1016/S0742-051X(97)00035-8.

Koludrovic, M., \& Radnic, I. (2013). The Contribution of Some Personal and Social Factors in Explaining School Achievement in Early Adolescence. Pedagogical Research, 10(1), 65-79.

Koludrovic, M. (2013). Problem - based learning in teacher education curriculum. Unpublished PhD thesis, University of Zagreb.

Koludrovic, M., \& Reic Ercegovac, I. (2013). Motivation and academic achievement: age and gender differences in goal orientation. Napredak, 154(4), 493-509.

Koludrovic, M., \& Reic Ercegovac, I. (2014). The Role of Classroom Environment in Students' Goal Orientations. Drustvena istrazivanja: Journal for General Social Issues, 23(2), 283-302. https://doi.org/10.5559/di.23.2.04

Koludrovic, M., \& Reic Ercegovac, I. (2015). Academic Motivation in the Context of Self-determination Theory in Initial Teacher Education. Croatian Journal of Education, 17(1spec.ed.), 25-36. https://doi.org/10.15516/cje.v17i0.1488

Koludrovic, M., Jukic, T., \& Reic Ercegovac, I. (2009). Burnout at classroom teachers, subject teachers and high school teachers. Life and School: Journal for the Theory and Practice of Education, 22(2), 235-249.

Lampert, J. N. (2007). The relationship of self-efficacy and self-concept to academic performance in a college sample: Testing competing models and measures. MSc diss, Pacific University. Retrieved from $\mathrm{http} / / /$ commons.pacificu.edu/cgi/viewcontent.cgi?article=1140\&context=spp

Levels of Autonomy and Responsibilities of Teachers in Europe. (2008). Retrieved September 8, 2015, from http://eacea.ec.europa.eu/education/eurydice/documents/thematic_reports/094en.pdf https://doi.org/10.2766/35479

Martin, L., West, J., \& Bill, K. (2008). Incorporating Problem - Based Learning Strategies to Develop Learner Autonomy and Employability Skills in Sports Science Undergraduates. Journal of Hospitality, Leisure, Sport and Tourism Education, 7(1), 18-30. https://doi.org/10.3794/johlste.71.169

Muller, F. H., \& Palekcic, M. (2005). Continuity of Motivation in Higher Education: A Three-Year Follow-Up Study. Review of Psychology, 12(1), 31-43. 
Nilsen, H. (2009). Influence on Student Academic Behaviour through Motivation, Self-Efficacy and Value-Expectation: An action research project to improve learning. Issues in Informing Science and Information Technology, 6, 545-556.

Owen, S.V., \& Froman, R. (1988). Development of a College self-efficacy scale. Paper presented at the Annual Meeting of the National Council on Measurement in Education, New Orleans, USA, April, 6-8.

Pollard, A., Collins, J., Anderson, J., Maddock, M., Swaffield, J. W., \& Warwick, P. (2008). Reflective Teaching: Evidence - Informed Professional Practice. London: Continuum International Publishing Group.

Richardson, V. (1996). The roles of attitudes and beliefs in learning to teach. In J. Sikula, T. J. Buttery, \& E. Guyton (Eds.), The Handbook of Research on Teacher Education (pp. 102-119). New York: Macmillan.

Rijavec, M., Miljevic - Ridicki, R., \& Vizek - Vidovic, V. (2006). Professional beliefs and perceived competences of pre-service teachers and beginning teachers. Educational sciences, 8(1), 159-170.

Ryan, R. M., \& Deci, E. L. (2000). Self-determination theory and the facilitation of intrinsic motivation, social development, and well-being. American Psychologist, 55, 68-78. https://doi.org/10.1037/0003-066X.55.1.68

Schunk, D. H. (1991). Self-efficacy and academic motivation. Educational Psychologist, 26(3-4), $207-231$. https://doi.org/10.1080/00461520.1991.9653133

Tschannen-Moran, M., \& Woolfolk Hoy, A. (2001). Teacher efficacy: Capturing an elusive construct. Teaching and Teacher Education, 17(7), 783-805. https://doi.org/10.1016/S0742-051X(01)00036-1

Vallerand, R. J., Pelletier, L. G., Blais, M. R., Briere, N. M., Senecal, C., \& Vallieres, E. F. (1992). The Academic Motivation Scale: A measure of intrinsic, extrinsic, and amotivation in education. Educational and Psychological Measurement, 52(4), 1003-1017. https://doi.org/10.1177/0013164492052004025

Vansteenkiste, M., Lens, W., \& Deci, E. L. (2006). Intrinsic versus extrinsic goal contents in self-determination theory: Another look at the quality of academic motivation. Educational Psychologist, 41(1), 19-31. https://doi.org/10.1207/s15326985ep4101_4

Woolfolk Hoy, A. (2000). Psicologia da Educacao.7a edicao. [The Psychology of Education. 7th ed]. Sao Paulo, Brasil: Edirora Artes Medicas Sul. 